\title{
Disclosure Information
}

\section{Relevant Disclosure Information}

Grant/Research Support from Bristol Myers Squibb, Roche, Merck

Consultant for Ventana Medical Systems

Employee of Foundation Medicine Inc.; Equity

Employee of Foundation Medicine Inc.

Employee of Foundation Medicine Inc.; Equity

Employee of Foundation Medicine Inc.; Equity

Employee of Foundation Medicine Inc.

Employee of Foundation Medicine Inc.

Grant/Research Support from Novartis Oncology

Grant/Research Support from Novartis Oncology; Board membership, honoraria

Consultant for Ventana Medical Systems; I have received honoraria and consult for Ventana Medical Systems. I am a coauthor on a patent issued to UM on ETS gene fusions in prostate cancer. The diagnostic field of use has been licensed to Gen-Probe Inc,

Employee of Genomic Health, Inc.; Stockholder

Employee of Genomic Health, Inc.; Stockholder

Employee of Genomic Health, Inc.; Stockholder

Employee of Genomic Health, Inc.; Stockholder

Employee of Genomic Health, Inc.; Stockholder

Employee of Genomic Health, Inc.; Stockholder

Employee of Genomic Health, Inc.; Stockholder

Employee of Genomic Health, Inc.; Stockholder

Consultant for Roche

Employee of Genomic Health, Inc.; Stockholder Employee of Genomic Health, Inc.; Stockholder

Employee of Genomic Health, Inc.; Stockholder

Employee of Genomic Health, Inc.; Stockholder

Employee of Genomic Health, Inc.

Employee of Genomic Health, Inc.; Stockholder

Employee of Genomic Health, Inc.

Employee of Genomic Health, Inc.; Stockholder

Employee of Genomic Health, Inc.; Stockholder

Genentech BioOncology; Genentech BioOncology Speakers Bureau Honorarium

Consultant for Bioreference Laboratories

Ventana Medical Systems, Inc.; Advisory Board for Ventana Medical Systems, Inc.

Consultant for Foundation Medicine Inc.; Stockholder

Consultant for Roche

Philips; Scientific Advisory Board for no compensation

Consultant for/Shareholder of MetaStat Inc.

Consultant for/Shareholder of MetaStat Inc.

Consultant for/Shareholder of MetaStat Inc.

Consultant for Grant/Research Support from Genomic Health Inc

Consultant for/Shareholder of MetaStat Inc.

Consultant for/Shareholder of MetaStat Inc.

Consultant for MetaStat Inc

Consultant for/Shareholder of MetaStat Inc.

Consultant for/Shareholder of MetaStat Inc.

Employee of Foundation Medicine Inc.

Employee of Foundation Medicine Inc.

Consultant for Grant/Research Support from ROCHE

Grant/Research Support from ROCHE

Grant/Research Support from ROCHE

ROCHE

Employee of Genentech

Employee of Genentech/Roche

Employee of Genentech/Roche

Grant/Research Support from Ventana Medical System Inc. 


\section{Abstract Name}

Rohit Bhargava

Krishan Kalra

Mahul Amin

Frederique Penault-Llorca

Jeffrey Ross

David Hicks

Rohit Bhargava

Laia Bernet

Kai Wang

Geoff Otto

Gary Palmer

Roman Yelenksy

Doron Lipson

Siraj Ali

Deborah Morosini

Vincent Miller

Philip Stephens

Jeffrey Ross

Baljit Singh

Steven Butler

Farid Jamshidian

Diana Cherbavaz

Amy Sing

Frederick Baehner

Vivian Tan

Frederick Baehner

Carl Yoshizawa

Joseph Anderson

Steven Shak

Alexander Valent

Alain Bernheim

Laurent Arnould

Gaetan MacGrogan

Jean-Marc Guinebretiere

Frederique Penault-Llorca

Magali Lacroix-Triki

Taisia Vitkovski

Zhen Wang

Christopher Lanigan

Vikram Deshpande

Vikram Deshpande

David Ting

Brendan Corcoran

Syd Finkelstein

Theresa Operana

Brock Schroeder

Catherine Schnabel

Zi-Xuan Wang

David Chhieng

David Chhieng

David Chhieng

David Chhieng

Andrew Fischer

Kai Wang

Geoff Otto

\section{Relevant Disclosure Information}

Ventana Medical Systems, Inc.; Advisory Board for Ventana Medical Systems, Inc.

Employee of BioGenex Laboratories

Employee of BioGenex Laboratories

ROCHE

Employee of Foundation Medicine Inc.

Genentech BioOncology; Genentech BioOncology Speakers Bureau Honorarium

Ventana Medical Systems, Inc.; Advisory Board for Ventana Medical Systems, Inc.

Sysmex Corp.; Sysmex payed for the molecular OSNA analysis of all the study

Employee of Foundation Medicine Inc.; Equity

Employee of Foundation Medicine Inc.; Equity

Employee of Foundation Medicine Inc.; Equity

Employee of Foundation Medicine Inc.

Employee of Foundation Medicine Inc.; Equity

Employee of Foundation Medicine Inc.

Employee of Foundation Medicine Inc.; Equity

Employee of Foundation Medicine Inc.; Equity

Employee of Foundation Medicine Inc.

Employee of Foundation Medicine Inc.

Consultant for Grant/Research Support from Genomic Health Inc, Genentech, Genoptix

Employee of Genomic Health, Inc.; As an employee of Genomic Health, Inc. I receive a salary and I own stock.

Employee of Genomic Health, Inc.

Employee of Genomic Health, Inc.; As an employee of Genomic Health, Inc. I receive a salary and I own stock.

Employee of Genomic Health, Inc.; Stockholder

Employee of Genomic Health, Inc.; Stockholder

Employee of Genomic Health, Inc.; Stockholder

Employee of Genomic Health, Inc.; Stockholder

Employee of Genomic Health, Inc.; Stockholder

Employee of Genomic Health, Inc.; Stockholder

Employee of Genomic Health, Inc.; Stockholder

Grant/Research Support from ROCHE

Grant/Research Support from ROCHE

Consultant for Grant/Research Support from ROCHE

Consultant for Roche

Consultant for ROCHE

ROCHE

Consultant for Grant/Research Support from ROCHE

Nikon camera.

Grant/Research Support from Advanced Cell Diagnostics

Grant/Research Support from Ventana Medical Systems Inc

Grant/Research Support from Affymetrix

Grant/Research Support from Affymetrix

Grant/Research Support from Affymetrix

Employee of RedPath Integrated Pathology, Inc.

Employee of RedPath Integrated Pathology, Inc.

Employee of bioTheranostics

Employee of bioTheranostics

Employee of bioTheranostics

Grant/Research Support from Vela Research Singapore Pte.Ltd.

Consultant for BD Diagnostics

Consultant for BD Diagnostics

Consultant for BD Diagnostics

Consultant for BD Diagnostics

Hologic Corporation; Dr. Andrew Fischer is an inventor of Cellient cell block technology, and he receives royalties for sales of Cellient products.

Employee of Foundation Medicine Inc.; Equity

Employee of Foundation Medicine Inc.; Equity 


\begin{tabular}{|c|c|}
\hline Abstract & Name \\
\hline 519 & Gary Palmer \\
\hline 519 & Roman Yelenksy \\
\hline 519 & Doron Lipson \\
\hline 519 & Gary Palmer \\
\hline 519 & Siraj Ali \\
\hline 519 & Deborah Morosini \\
\hline 519 & Vincent Miller \\
\hline 519 & Philip Stephens \\
\hline 519 & Jeffrey Ross \\
\hline 548 & Maria Latorre \\
\hline 548 & Mariano Carrizo \\
\hline 548 & Fabian Moffa \\
\hline 555 & Hongwei Wang \\
\hline 555 & Zhen Wang \\
\hline 555 & Christopher Lanigan \\
\hline 555 & Yuling Luo \\
\hline 555 & Xiao-Jun Ma \\
\hline 567 & Colleen Rock \\
\hline 567 & Kelsey Moyes \\
\hline 567 & M Bryan Warf \\
\hline 567 & Sancy Leachman \\
\hline 567 & Loren Clarke \\
\hline 572 & Pedram Gerami \\
\hline 576 & Ryan Bremer \\
\hline 576 & Charlie Yu \\
\hline 576 & Laura Hoang \\
\hline 600 & Magali Lacroix-Triki \\
\hline 617 & Yuri Nikiforov \\
\hline 634 & Yuri Nikiforov \\
\hline 640 & Kai Wang \\
\hline 640 & Geoff Otto \\
\hline 640 & Gary Palmer \\
\hline 640 & Roman Yelenksy \\
\hline 640 & Doron Lipson \\
\hline 640 & Juliann Chmielecki \\
\hline 640 & Siraj Ali \\
\hline 640 & Deborah Morosini \\
\hline 640 & Vincent Miller \\
\hline 640 & Philip Stephens \\
\hline 640 & Jeffrey Ross \\
\hline 656 & Paul Roepman \\
\hline 656 & Iris Simon \\
\hline 659 & Siraj Ali \\
\hline 659 & Kai Wang \\
\hline 659 & Geoff Otto \\
\hline 659 & Gary Palmer \\
\hline 659 & Roman Yelensky \\
\hline 659 & Doron Lipson \\
\hline 659 & Deborah Morosini \\
\hline 659 & Vincent Miller \\
\hline 659 & Phillip Stephens \\
\hline 659 & Jeffrey Ross \\
\hline 667 & Sydney Finkelstein \\
\hline 667 & Mindi Styn \\
\hline 672 & David Ting \\
\hline 672 & Miguel Rivera \\
\hline 672 & Vikram Deshpande \\
\hline 693 & Miriam Cuatrecasas \\
\hline 693 & Iban Aldecoa \\
\hline 693 & Jordi Tarragona \\
\hline
\end{tabular}

\section{Relevant Disclosure Information}

Employee of Foundation Medicine Inc.; Equity

Employee of Foundation Medicine Inc.

Employee of Foundation Medicine Inc.; Equity

Employee of Foundation Medicine Inc.; Equity

Employee of Foundation Medicine Inc.

Employee of Foundation Medicine Inc.; Equity

Employee of Foundation Medicine Inc.; Equity

Employee of Foundation Medicine Inc.

Employee of Foundation Medicine Inc.

Employee of Productos Roche

Employee of Productos Roche

Employee of Productos Roche

Employee of Advanced Cell Diagnostics, Inc.

Grant/Research Support from Advanced Cell Diagnostics, Inc.

Grant/Research Support from Ventana Medical Systems, Inc

Employee of/Stockholder of Advanced Cell Diagnostics, Inc.

Employee of/Stockholder of Advanced Cell Diagnostics, Inc.

Employee of Myriad Genetic Laboratories, Inc.

Employee of Myriad Genetic Laboratories, Inc.

Employee of Myriad Genetic Laboratories, Inc.

Consultant for Grant/Research Support from Myriad Genetic Laboratories, Inc.

Employee of Myriad Genetic Laboratories, Inc.

Consultant for Castle Biosciences

Employee of Biocare Medical

Employee of Biocare Medical

Employee of Biocare Medical

Consultant for Grant/Research Support from ROCHE

Consultant for Quest Diagnostics

Consultant for Quest Diagnostics

Employee of Foundation Medicine Inc.; Equity

Employee of Foundation Medicine Inc.; Equity

Employee of Foundation Medicine Inc.; Equity

Employee of Foundation Medicine Inc.

Employee of Foundation Medicine Inc.; Equity

Employee of Foundation Medicine Inc.

Employee of Foundation Medicine Inc.

Employee of Foundation Medicine Inc.; Equity

Employee of Foundation Medicine Inc.; Equity

Employee of Foundation Medicine Inc.

Employee of Foundation Medicine Inc.

Employee of Agendia

Employee of Agendia

Employee of Foundation Medicine Inc.

Employee of Foundation Medicine Inc.; Equity

Employee of Foundation Medicine Inc.; Equity

Employee of Foundation Medicine Inc.; Equity

Employee of Foundation Medicine Inc.; Equity

Employee of Foundation Medicine Inc.; Equity

Employee of Foundation Medicine Inc.; Equity

Employee of Foundation Medicine Inc.; Equity

Employee of Foundation Medicine

Employee of Foundation Medicine; Equity

Employee of RedPath Integrated Pathology, Inc.

Employee of RedPath Integrated Pathology, Inc.

Grant/Research Support from Affymetrix

Grant/Research Support from Affymetrix

Grant/Research Support from Affymetrix

Sysmex Corp.; Sysmex payed for the molecular OSNA analysis of all the study Sysmex Corp; Sysmex payed for the molecular OSNA analysis of all the study Sysmex Corp.; Sysmex payed for the molecular OSNA analysis of all the study 


\section{Abstract Name}

693
Begona Atares Laia Bernet

Teresa Pereda

Jose Palacios

Javier Zamora

Miriam Cuatrecasas

Iban Aldecoa

Laura Herrero

David Hicks

Christa Whitney-Miller

David Hicks

Christa Whitney-Miller

Yasunori Nishida

Takeshi Kuwata

Hiroaki Nitta

Atsushi Ochiai

Vikram Deshpande

Miguel Rivera

David Ting

Vikram Deshpande

David Ting

Vikram Deshpande

Mark Evans

Kai Wang

Geoff Otto

Gary Palmer

Siraj Ali

Deborah Morosini

Vincent Miller

Philip Stephens

Jeffrey Ross

Margaret Gulley

Wade Samowitz

Christa Whitney-Miller

Chanan Sluszny

David Hicks

Gloria Zhang

Christopher Lanigan

Tricia Bal

Bonnie LaFLeur

Shalini Singh

Gloria Zhang

Jeffrey Ross

Francesca Demichelis

Scott Tomlins

Arul Chinnaiyan

Francesca Demichelis

Kathryn Kolquist

Matthew Cooperberg

Stephen Freedland

Julia Reid

Steven Stone

Michael Brawer

Hanlin Gao

Lawrence Weiss

Weimin Peng

Thian Kheoh

NamPhuong Tran

Arturo Molina

\section{Relevant Disclosure Information}

Sysmex Corp.; Sysmex payed for the molecular OSNA analysis of all the study Sysmex Corp.; Sysmex payed for the molecular OSNA analysis of all the study Sysmex Corp.; Sysmex payed for the molecular OSNA analysis of all the study Sysmex Corp.; Sysmex payed for the molecular OSNA analysis of all the study Consultant for Sysmex Corp.

Sysmex Corp.; Sysmex payed for the molecular OSNA analysis of all the study Sysmex Corp; Sysmex payed for the molecular OSNA analysis of all the study Sysmex Corp.; Sysmex payed for the molecular OSNA analysis of all the study Genentech BioOncology; Genentech BioOncology Speakers Bureau Honorarium Grant/Research Support from Genentech

Genentech BioOncology; Genentech BioOncology Speakers Bureau Honorarium Grant/Research Support from Genentech

Grant/Research Support from Ventana Medical Systems, Inc.

Grant/Research Support from Ventana Medical Systems, Inc.

Employee of Ventana Medical Systems, Inc.

Consultant for Ventana Medical Systems, Inc.

Grant/Research Support from Affymetrix

Grant/Research Support from Affymetrix

Grant/Research Support from Affymetrix

Grant/Research Support from Affymetrix

Grant/Research Support from Affymetrix

Grant/Research Support from Affymetrix

Grant/Research Support from Dako

Employee of Foundation Medicine Inc.; Equity

Employee of Foundation Medicine Inc.

Employee of Foundation Medicine Inc.; Equity

Employee of Foundation Medicine Inc.

Employee of Foundation Medicine Inc.; Equity

Employee of Foundation Medicine Inc.; Equity

Employee of Foundation Medicine Inc.

Employee of Foundation Medicine Inc.

Consultant for Roche, McKesson, Abbott and Generation Health

Ventana; Royalty, receipt of intellectual property rights/property holder

Grant/Research Support from Genentech

Employee of Applied Spectral Imaging, Ltd.

Genentech BioOncology; Genentech BioOncology Speakers Bureau Honorarium

Ventana Medical Systems Inc

Grant/Research Support from Ventana Medical Systems Inc

Employee of Ventana Medical Systems Inc

Employee of Ventana Medical Systems Inc

Employee of Ventana Medical Systems Inc

Ventana Medical Systems Inc

Employee of Foundation Medicine, Inc.

Grant/Research Support from Ventana Medical Systems

Consultant for Ventana Medical Systems; I have received honoraria and consult for Ventana Medical Systems. I am a coauthor on a patent issued to UM on ETS gene fusions in prostate cancer. The diagnostic field of use has been licensed to Gen-Probe Inc,

Consultant for Ventana Medical Systems

Grant/Research Support from Ventana Medical Systems

Employee of Myriad Genetic Laboratories, Inc.

Consultant for GenomeDx Biosciences, Inc.

Consultant for Bayer

Employee of Myriad Genetics, Inc.

Employee of Myriad Genetics, Inc.

Employee of Myriad Genetic Laboratories, Inc.

Employee of Fulgent Therapeutics

Employee of Clarient

Employee of Janssen Research \& Development

Employee of Janssen Research \& Development; Owns stock in Johnson \& Johnson Employee of Janssen Research \& Development; Owns stock in Johnson \& Johnson Employee of Janssen Research \& Development; Owns stock in Johnson \& Johnson 


\begin{tabular}{|c|c|}
\hline Abstract & Name \\
\hline 1009 & Philip Kantoff \\
\hline 1009 & Patricia Troncoso \\
\hline 1012 & Jeremy Squire \\
\hline 1012 & David Berman \\
\hline 1016 & S Campbell \\
\hline 1016 & $\mathrm{C} \mathrm{Ma}$ \\
\hline 1016 & B Gowrishankar \\
\hline 1016 & J Houldsworth \\
\hline 1020 & Arul Chinnaiyan \\
\hline 1020 & Scott Tomlins \\
\hline 1055 & Jeffrey Ross \\
\hline 1055 & Kai Wang \\
\hline 1055 & Laurie Gay \\
\hline 1055 & Geoff Otto \\
\hline 1055 & Amy Donahue \\
\hline 1055 & Jie He \\
\hline 1055 & Gary Palmer \\
\hline 1055 & Siraj Ali \\
\hline 1055 & Michelle Nahas \\
\hline 1055 & Geneva Young \\
\hline 1055 & Elaine LaBrecque \\
\hline 1055 & Garrett Frampton \\
\hline 1055 & Rachel Erlich \\
\hline 1055 & John Curran \\
\hline 1055 & Kristina Brennan \\
\hline 1055 & Sean Downing \\
\hline 1055 & Roman Yelensky \\
\hline 1055 & Doron Lipson \\
\hline 1055 & Matthew Hawryluk \\
\hline 1055 & Vincent Miller \\
\hline 1055 & Philip Stephens \\
\hline 1070 & Andrew Evans \\
\hline 1078 & Scott Tomlins \\
\hline 1085 & Jeffrey Ross \\
\hline 1088 & Steven Stirdivant \\
\hline 1088 & Bruce Neri \\
\hline 1088 & Robert Wolfert \\
\hline 1091 & Jeremy Squire \\
\hline 1097 & Scott Tomlins \\
\hline
\end{tabular}

1097 Arul Chinnaiyan

$1097 \quad$ Rohit Mehra

1098 Arul Chinnaiyan

\section{Relevant Disclosure Information}

Consultant for Grant/Research Support from Janssen Research \& Development

Consultant for Grant/Research Support from Janssen Research \& Development; Honoraria from Janssen Research \& Development

Consultant for CymoGen Dx LLC; Recipient of licensing fees based on patent for probe design. Consultant for Grant/Research Support from Myriad Genetics

Grant/Research Support from Pfizer; Investigator, speaker

Employee of Cancer Genetics Inc.

Employee of Cancer Genetics Inc.

Employee of Cancer Genetics Inc.; stock holder

Consultant for Ventana Medical Systems

Consultant for Ventana Medical Systems; I have received honoraria and consult for Ventana Medical Systems. I am a coauthor on a patent issued to UM on ETS gene fusions in prostate cancer. The diagnostic field of use has been licensed to Gen-Probe Inc,

Employee of Foundation Medicine Inc.

Employee of Foundation Medicine Inc.; Equity

Employee of Foundation Medicine Inc.

Employee of Foundation Medicine Inc.; Equity

Employee of Foundation Medicine Inc.

Employee of Foundation Medicine Inc.

Employee of Foundation Medicine Inc.; Equity

Employee of Foundation Medicine Inc.

Employee of Foundation Medicine Inc.

Employee of Foundation Medicine Inc.

Employee of Foundation Medicine Inc.

Employee of Foundation Medicine Inc.

Employee of Foundation Medicine Inc.

Employee of Foundation Medicine Inc.

Employee of Foundation Medicine Inc.

Employee of Foundation Medicine Inc.

Employee of Foundation Medicine Inc.; Equity

Employee of Foundation Medicine Inc.; Equity

Employee of Foundation Medicine Inc.

Employee of Foundation Medicine Inc.; Equity

Employee of Foundation Medicine Inc.

Consultant for Omnyx LLC

Consultant for Ventana Medical Systems; I have received honoraria and consult for Ventana Medical Systems. I am a coauthor on a patent issued to UM on ETS gene fusions in prostate cancer. The diagnostic field of use has been licensed to Gen-Probe Inc,

Employee of Foundation Medicine, Inc.

Employee of Metabolon, Inc.

Employee of Metabolon, Inc.

Employee of Metabolon, Inc.

Consultant for CymoGen Dx LLC; Recipient of licensing fees based on patent for probe design. Consultant for Gen-Probe and Ventana Medical Systems; The University of Michigan has been issued a patent on the detection of ETS gene fusions in prostate cancer, on which S.A.T. is listed as a co-inventor and which has been licensed to Gen-Probe, who has sub-licensed some rights to Ventana Medical Systems.

Consultant for Gen-Probe and Ventana Medical Systems; The University of Michigan has been issued a patent on the detection of ETS gene fusions in prostate cancer, on which A.M.C. is listed as a co-inventor and which has been licensed to Gen-Probe, who has sub-licensed some rights to Ventana Medical Systems.

Consultant for GenomeDx Biosciences; The University of Michigan has been issued a patent on the detection of ETS gene fusions in prostate cancer, on which R.M. is listed as a co-inventor and which has been licensed to Gen-Probe, who has sub-licensed some rights to Ventana Medical Systems.

Consultant for Gen-Probe and Ventana Medical Systems; The University of Michigan has been issued a patent on the detection of ETS gene fusions in prostate cancer, on which A.M.C. is listed as a co-inventor and which has been licensed to Gen-Probe, has sub-licensed some rights to Ventana Medical Systems. 
Abstract Name

1098 Rohit Mehra

$1101 \quad$ Andrew Evans

1107 Scott Tomlins

1120 Scott Tomlins

1120

1174

1184

1184

1184

1184

1184

1184

1184

1184

1184

1184

1194

1194

1223

1238

1256

1258

1259

1260

1268

1268

1343

1359

1415

1415

1423

1423

1423

1423

1423

1429

1429

1440

1440

1460

1461

1461

1461

1478

1479

1486

1507

1507

1528

1528

1531
Arul Chinnaiyan

Gloria Zhang

Geoff Otto

Kai Wang

Gary Palmer

Roman Yelensky

Doron Lipson

Siraj Ali

Deborah Morosini

Vincent Miller

Philip Stephens

Jeffrey Ross

David Dabbs

Rohit Bhargava

Mark Stoler

Mark Stoler

Rohit Bhargava

Jose Palacios

Lauren Powlovich

Mark Evans

David Wilbur

Mark Stoler

Arul Chinnaiyan

Mark Evans

Jork Nolling

Lilly Kong

Henry Dong

Steve Beachman

Veena Suri

Min Yang

Pauline Brenholz

Richard Furman

Betty Chang

Jork Nolling

Lilly Kong

Hagop Kantarjian

Miguel Rivera

David Ting

Vikram Deshpande

Hagop Kantarjian

Hagop Kantarjian

James Mansfield

Dennis O[apos]Malley

Lawrence Weiss

Kaida $\mathrm{Wu}$

Abhay Patki

Lisa Rimsza

\section{Relevant Disclosure Information}

Consultant for GenomeDx Biosciences; The University of Michigan has been issued a patent on the detection of ETS gene fusions in prostate cancer, on which R.M. is listed as a co-inventor and which has been licensed to Gen-Probe, who has sub-licensed some rights to Ventana Medical Systems.

Consultant for Omnyx LLC

Consultant for Ventana Medical Systems; I have received honoraria and consult for Ventana Medical Systems. I am a coauthor on a patent issued to UM on ETS gene fusions in prostate cancer. The diagnostic field of use has been licensed to Gen-Probe, Inc.

Consultant for Ventana Medical Systems; I have received honoraria and consult for Ventana Medical Systems. I am a coauthor on a patent issued to UM on ETS gene fusions in prostate cancer. The diagnostic field of use has been licensed to Gen-Probe Inc,

Consultant for Ventana Medical Systems

Ventana Medical Systems Inc

Employee of Foundation Medicine Inc.

Employee of Foundation Medicine Inc.; Equity

Employee of Foundation Medicine Inc.; Equity

Employee of Foundation Medicine Inc.; Equity

Employee of Foundation Medicine Inc.; Equity

Employee of Foundation Medicine Inc.

Employee of Foundation Medicine Inc.; Equity

Employee of Foundation Medicine Inc.; Equity

Employee of Foundation Medicine Inc.

Employee of Foundation Medicine Inc.

Grant/Research Support from Ventana Medical System Inc.

Ventana Medical Systems, Inc.; Advisory Board for Ventana Medical Systems, Inc.

Consultant for Ventana

Consultant for Ventana

Ventana Medical Systems, Inc.; Advisory Board for Ventana Medical Systems, Inc.

Sysmex Corp.; Sysmex payed for the molecular OSNA analysis of all the study

Grant/Research Support from Dako

Grant/Research Support from Dako

Philips; Scientific Advisory Board for no compensation

Consultant for Ventana

Consultant for Ventana Medical Systems

Grant/Research Support from Dako

Employee of PrimeraDx

Employee of PrimeraDx

Employee of Labcorp

Employee of Labcorp

Employee of Labcorp

Employee of Labcorp

Employee of Labcorp

Consultant for Pharmacyclics, Inc.

Employee of Pharmacyclics, Inc.

Employee of PrimeraDx

Employee of PrimeraDx

Consultant for Grant/Research Support from Incyte, Novartis

Grant/Research Support from Affymetrix

Grant/Research Support from Affymetrix

Grant/Research Support from Affymetrix

Consultant for Grant/Research Support from Incyte, Novartis

Consultant for Grant/Research Support from Incyte, Novartis

Employee of PerkinElmer

Employee of Clarient Inc./GE Healthcare

Employee of Clarient Inc./GE Healthcare

Employee of Sanofi

Employee of Sanofi Oncology

Ventana Medical Systems; Ventana Medical Systems manufactures one of the antibodies used in this project. Ventana also makes an unrestricted donation to the University of Arizona,

Department of Pathology. Dr. Rimsza has access to these University funds 


\begin{tabular}{|c|c|}
\hline Abstract & Name \\
\hline 1540 & Jeffrey Ross \\
\hline 1540 & Michelle Nahas \\
\hline 1540 & Doron Lipson \\
\hline 1540 & Geoff Otto \\
\hline 1540 & Roman Yelensky \\
\hline 1540 & Kai Wang \\
\hline 1540 & Jie $\mathrm{He}$ \\
\hline 1540 & Kristina Brennan \\
\hline 1540 & Geneva Young \\
\hline 1540 & Amy Donahue \\
\hline 1540 & Garrett Frampton \\
\hline 1540 & Lauren Young \\
\hline 1540 & Vincent Miller \\
\hline 1540 & Philip Stephens \\
\hline 1550 & Ross Levine \\
\hline 1550 & Andrew Zelenetz \\
\hline 1550 & Lia Palomba \\
\hline 1550 & Marcel Van den Brin \\
\hline 1550 & Kristina Brennan \\
\hline 1550 & Geneva Young \\
\hline 1550 & Jie He \\
\hline 1550 & Michelle Nahas \\
\hline 1550 & Roman Yelenski \\
\hline 1550 & Geoff Otto \\
\hline 1550 & Doron Lipson \\
\hline 1550 & Philip Stephens \\
\hline 1550 & Vincent Miler \\
\hline 1550 & Anas Younes \\
\hline 1550 & Andrew Intlekofer \\
\hline 1556 & Gordon Freeman \\
\hline 1569 & Zhen Wang \\
\hline 1569 & Hongwei Wang \\
\hline 1569 & Christopher Lanigan \\
\hline 1569 & Yuling Luo \\
\hline 1569 & Xiao-Jun Ma \\
\hline 1570 & Christopher Lanigan \\
\hline 1571 & Zi-Xuan Wang \\
\hline 1571 & Peter Banks \\
\hline 1571 & Jerald Gong \\
\hline 1583 & Asha Guttapalli \\
\hline 1583 & Charles Ma \\
\hline 1583 & Houldsworth Jane \\
\hline 1629 & Kathryn Espig \\
\hline 1629 & Albert Xthona \\
\hline 1630 & Toby Cornish \\
\hline 1632 & Andrew Evans \\
\hline 1633 & Charles Law \\
\hline 1639 & Laura Drogowski \\
\hline 1639 & Vipul Baxi \\
\hline 1639 & Michael Montalo \\
\hline 1641 & Nabeel Memon \\
\hline 1641 & Sean Costello \\
\hline 1641 & Azita Sharif \\
\hline 1648 & Taisia Vitkovski \\
\hline 1649 & Taisia Vitkovski \\
\hline 1650 & Jonhan Ho \\
\hline 1651 & David Wilbur \\
\hline 1651 & John Gilbertson \\
\hline 1651 & John Vallone \\
\hline 1654 & Peter Hufnagl \\
\hline 1672 & Flavio Vincenti \\
\hline
\end{tabular}

\section{Relevant Disclosure Information}

Employee of Foundation Medicine Inc.

Employee of Foundation Medicine Inc.

Employee of Foundation Medicine Inc.; Equity

Employee of Foundation Medicine Inc.; Equity

Employee of Foundation Medicine Inc.; Equity

Employee of Foundation Medicine Inc.; Equity

Employee of Foundation Medicine Inc.

Employee of Foundation Medicine Inc.

Employee of Foundation Medicine Inc.

Employee of Foundation Medicine Inc.

Employee of Foundation Medicine Inc.

Employee of Foundation Medicine Inc.

Employee of Foundation Medicine Inc.; Equity

Employee of Foundation Medicine Inc.

Consultant for Foundation Medicine Inc.

Consultant for Foundation Medicine Inc.

Consultant for Foundation Medicine Inc.

Consultant for Foundation Medicine Inc.

Employee of Foundation Medicine Inc.

Employee of Foundation Medicine Inc.

Employee of Foundation Medicine Inc.

Employee of Foundation Medicine Inc.

Employee of Foundation Medicine Inc.

Employee of Foundation Medicine Inc.

Employee of Foundation Medicine Inc.

Employee of Foundation Medicine Inc.

Employee of Foundation Medicine Inc.

Consultant for Foundation Medicine Inc.

Consultant for Foundation Medicine Inc.

Consultant for Jounce Pharmaceuticals

Grant/Research Support from Advanced Cell Diagnostics

Employee of Advanced Cell Diagnostics, Inc.

Grant/Research Support from Ventana Medical Systems Inc

Employee of/Shareholder of Advanced Cell Diagnostics

Employee of/Shareholder of Advanced Cell Diagnostics

Grant/Research Support from Ventana Medical Systems Inc

Grant/Research Support from Vela Research Singapore Pte.Ltd.

Consultant for Ventana Medical Systems Inc.

Grant/Research Support from Ventana Medical Systems Inc.

Employee of Cancer Genetics Inc.

Employee of Cancer Genetics Inc.

Employee of Cancer Genetics Inc.

Employee of Barco Healthcare

Employee of Barco Healthcare

DigiPath; Member of Scientific Advisory Board, Minor Stockholder

Consultant for Omnyx LLC

Employee of Kitware Inc

Employee of Omnyx

Employee of Omnyx

Employee of Omnyx

Employee of DSI- The Biobank Automation Co,

Employee of Leica Biosystems, Inc.

Employee of DSI

Nikon camera

Nikon camera

Grant/Research Support from Omnyx

Philips; Scientific Advisory Board for no compensation

Philips; Scientific Advisory Board

Philips; Scientific Advisory Board for no compensation

Stockholder of VMScope GmbH

Grant/Research Support from Bristol-Myers Squibb 


\begin{tabular}{|c|c|c|}
\hline Abstract & Name & Relevant Disclosure Information \\
\hline 1693 & Flavio Vincenti & Grant/Research Support from Bristol-Myers Squibb \\
\hline 1708 & John Iafrate & Consultant for Bioreference Laboratories \\
\hline 1764 & Miguel Rivera & Grant/Research Support from Affymetrix \\
\hline 1811 & Kenneth Hensley & $\begin{array}{l}\text { Stockholder of XoNovo Inc.; Inventor of the technology referenced in this proposal and acting } \\
\text { chief scientist for the licensee company, XoNovo Inc. }\end{array}$ \\
\hline 1846 & Vikram Deshpande & Grant/Research Support from Affymetrix \\
\hline 1847 & Vikram Deshpande & Grant/Research Support from Affymetrix \\
\hline 1852 & Suresh Thakur & Employee of BioGenex Laboratories \\
\hline 1852 & Snigdha Sahu & Employee of BioGenex Inc \\
\hline 1890 & Jeffrey Ross & Employee of Foundation Medicine Inc.; Equity \\
\hline 1890 & Gary Palmer & Employee of Foundation Medicine Inc.; Equity \\
\hline 1890 & Roman Yelensky & Employee of Foundation Medicine Inc.; Equity \\
\hline 1890 & Maureen Cronin & Employee of Foundation Medicine Inc. \\
\hline 1890 & Vincent Miller & Employee of Foundation Medicine Inc.; Equity \\
\hline 1890 & Phillip Stephens & Employee of Foundation Medicine Inc. \\
\hline 1921 & Brendan Corcoran & Employee of RedPath Integrated Pathology, Inc. \\
\hline 1921 & Syd Finkelstein & Employee of RedPath Integrated Pathology, Inc. \\
\hline 1937 & Maura Menghi & Employee of Diatech Pharmacogenetics \\
\hline 1955 & Julie Brahmer & Consultant for Bristol-Meyer Squibb \\
\hline 1956 & Kai Wang & Employee of Foundation Medicine Inc.; Equity \\
\hline 1956 & Philip Stephens & Employee of Foundation Medicine Inc. \\
\hline 1956 & Jeffrey Ross & Employee of Foundation Medicine Inc. \\
\hline 1969 & Wei-Li Liao & Employee of OncoPlex Diagnostics \\
\hline 1969 & Jon Burrows & Employee of OncoPlex Diagnostics \\
\hline 1969 & Todd Hembrough & Employee of OncoPlex Diagnostics \\
\hline 1983 & Jeffrey Ross & Employee of Foundation Medicine Inc. \\
\hline 1987 & James Suh & Consultant for Pfizer; Speaker \\
\hline 2007 & Christopher Lanigan & Grant/Research Support from Ventana Medical Systems Inc \\
\hline 2007 & Zhen Wang & Grant/Research Support from Advanced Cell Diagnostics \\
\hline 2018 & Jeffrey Ross & Employee of Foundation Medicine Inc. \\
\hline 2031 & Zi-Xuan Wang & Grant/Research Support from Vela Research Singapore Pte.Ltd. \\
\hline 2043 & John Bomalaski & Employee of Stockholder of Polaris Pharmaceuticals, Inc. \\
\hline 2086 & Gregory Henderson & Employee of Consultant for/Shareholder of PathForcedx, LLC \\
\hline 2108 & Michael Tompkins & Employee of Leica Microsystems \\
\hline 2115 & Torsten Nielsen & $\begin{array}{l}\text { Bioclassifier, LLC; Dr. Nielsen discloses that he is a co-founder of Bioclassifier, LLC which } \\
\text { licensed the PAM } 50 \text { algorithm to NanoString Technologies }\end{array}$ \\
\hline 2120 & Garry Nolan & Consultant for DVS Sciences \\
\hline 2122 & Helen Bailey & Employee of Genomic Health, Inc.; Stockholder \\
\hline 2122 & Carl Millward & Employee of Genomic Health, Inc.; Stockholder \\
\hline 2122 & Seth Michelson & Employee of Genomic Health, Inc.; Stockholder \\
\hline 2122 & Frederick Baehner & Employee of Genomic Health, Inc.; Stockholder \\
\hline 2123 & Crystal Falco & Employee of Enzium, Inc. \\
\hline 2123 & Sydney Finkelstein & Employee of RedPath Integrated Pathology, Inc. \\
\hline
\end{tabular}




$\begin{array}{ll}\text { Abstract } & \text { Name } \\ 2135 & \text { C Charles Law } \\ 2139 & \text { Gretchen King } \\ 2140 & \text { Clifford Hoyt } \\ 2140 & \text { Chichung Wang } \\ 2140 & \text { Kristin Roman } \\ 2144 & \text { Norbert Varga } \\ 2144 & \text { Marta Benczik } \\ 2144 & \text { Albrecht Brandenburg } \\ 2145 & \text { Lucia Lam } \\ 2145 & \text { Nicholas Erho } \\ 2145 & \text { Thomas Sierocinski } \\ 2145 & \text { Hugh Wellman } \\ 2145 & \text { Elai Davicioni } \\ 2145 & \text { Matthew Cooperberg } \\ 2147 & \text { Rohit Bhargava } \\ 2153 & \text { Mehrdad Nadji } \\ 2153 & \text { Azorides Morales } \\ 2158 & \text { Joan Jones } \\ 2158 & \text { John Condeelis } \\ 2163 & \text { Jeffrey Ross } \\ 2163 & \text { Kai Wang } \\ 2163 & \text { Geoff Otto } \\ 2163 & \text { Gary Palmer } \\ 2163 & \text { Roman Yelensky } \\ 2163 & \text { Doron Lipson } \\ 2163 & \text { Juliann Chmielecki } \\ 2163 & \text { Siraj Ali } \\ 2163 & \text { Deborah Morosini } \\ 2163 & \text { Vincent Miller } \\ 2163 & \text { Philip Stephens } \\ 2164 & \text { Sandra Rost } \\ 2164 & \text { Chenery Lowe } \\ 2164 & \text { Hartmut Koeppen } \\ 2173 & \text { John Thorson } \\ 2173 & \text { Sarah Murray } \\ 2176 & \text { Brendan Corcoran } \\ 2176 & \text { Syd Finkelstein } \\ & \end{array}$

\section{Relevant Disclosure Information}

Employee of Kitware Inc

Employee of BIO SB, Inc.

Employee of Perkin Elmer

Employee of Perkin Elmer

Employee of Perkin Elmer

Employee of GenoID Ltd

Employee of GenoID Ltd

Employee of Fraunhoffer IPM

Employee of GenomeDx Biosciences Inc.

Employee of GenomeDx Biosciences Inc.

Employee of GenomeDx Biosciences Inc.

Employee of GenomeDx Biosciences Inc.

Employee of Stockholder of GenomeDx Biosciences Inc.

Consultant for GenomeDx Biosciences Inc.

Ventana Medical Systems, Inc.; Advisory Board for Ventana Medical Systems, Inc.

Sakura Finetek; Royalties

Sakura Finetek; Royalties

Consultant for/Shareholder of MetaStat Inc.

Consultant for/Shareholder of MetaStat Inc.

Employee of Foundation Medicine Inc.

Employee of Foundation Medicine Inc.; Equity

Employee of Foundation Medicine Inc.

Employee of Foundation Medicine Inc.; Equity

Employee of Foundation Medicine Inc.; Equity

Employee of Foundation Medicine Inc.; Equity

Employee of Foundation Medicine Inc.

Employee of Foundation Medicine Inc.

Employee of Foundation Medicine Inc.

Employee of Foundation Medicine Inc.

Employee of Foundation Medicine Inc.

Employee of Genentech/Roche

Consultant for Genentech/Roche

Employee of Genentech/Roche

Consultant for Illlumina

Illumina; Speaker fee for user group meeting

Employee of RedPath Integrated Pathology, Inc.

Employee of RedPath Integrated Pathology, Inc. 